\title{
Imaging the Jungles of Calais: Media Visuality and the Refugee Camp
}

\author{
YASMIN IBRAHIM Queen Mary, University of London
}

ANITA HOWARTH Brunel University London

\begin{abstract}
Calais became a space of renewed media interest in the summer of 2015, with an increased visuality into the state of refugees' living conditions and their lives. We examine the images of the camps dubbed 'the Jungle' over time, when media started reporting on the camp which was demolished in 2009 and the more recent resurrections termed as 'Jungle II' or the 'new Jungle', thereafter. Earlier media coverage of the Jungle accompanied less visual depictions of their living conditions or daily existence beyond the threat they posed to their immediate environment. However, compared to 2009 there has been a surge in the number of images of the refugees, particularly a steep rise in 2014 and 2015. The refugee as an object of suffering and trauma is the subject of an abject gaze where the corporeal body is both a non-entity and invisible. Both death and the accident are ascribed to it, as inhabitants in this 'state of exception'. We examine these aesthetics of trauma and violence in the liminal space of Calais. The increased visuality and curiosity in the camps since 2015 reinscribed the refugee as a political by-product of border politics, accentuating the refugee camp as a violent and dissonant space in civilised Europe. Despite the intimacy of the imagery, the increased visuality showcased the madness and futility produced through a border politics of legitimacy and 'bare life'.
\end{abstract}

\section{KEYWORDS}

Calais, migrants, visuality, refugee camps, the Jungle

\section{Introduction}

In September 2009 in the full glare of media cameras, riot police demolished an informal refugee camp near the port of Calais known as 'the Jungle' (Howarth \& Ibrahim 2012; Ibrahim \& Howarth 2015a; 2015b; Ibrahim 2011). The French government legitimised their overt actions, claiming that the Jungle had become a base for people traffickers who were targeting the United Kingdom as their ultimate destination. The militant action was welcomed by the British newspapers as constituting decisive action by the French to counter illegal migration across the Channel. The demolition of the Jungle became a major news event for British media, where the spectacle of police brutality provided a theatre of cruelty with images of riot police and mighty bulldozers juxtaposed against flattened tents and tearful refugees. The demolition event of 2009 was devised as a media spectacle by the authorities to impress their spatial control over Calais (Sparks 2010). As such, the images centralised the demolition machine, with the refugees being a minute side act. Our analysis of Calais, which captured the ebbs and flows of imaging the migrant crisis, reveals a shifting visuality between 
2003 and 2015; manifest partly in an intensification in imagining, and partly in dominant discourses constructed around themes of destruction, brutality and violence as well as in the emergence of a quasi-settlement where the pleasure in the media rituals of demolition is replaced by an intrusive, inquisitive and transgressive gaze into the Other. In contrast to the 2009 spectacle, the five camp demolitions in 2014 and 2015 were relatively low-key events with only a handful of journalists present and relatively few images capturing the destruction, where the discourse for destruction had shifted from rooting out lawlessness to dealing with public health concerns (Allen 2014).

Despite the stark imagery of the first demolition, new camps sprung up overnight to replace those destroyed. The French police then continued their ritual of razing these down to the ground with their mammoth bulldozers. Hence the 'jungles' of 2009 never really disappeared and in the next few years remained in a liminal site of what Agamben terms the 'state of exception' inhabited by 'bare life'; a form of life whose status is indistinct and not governed by conventional law or politics (Agamben 1998; 2000).

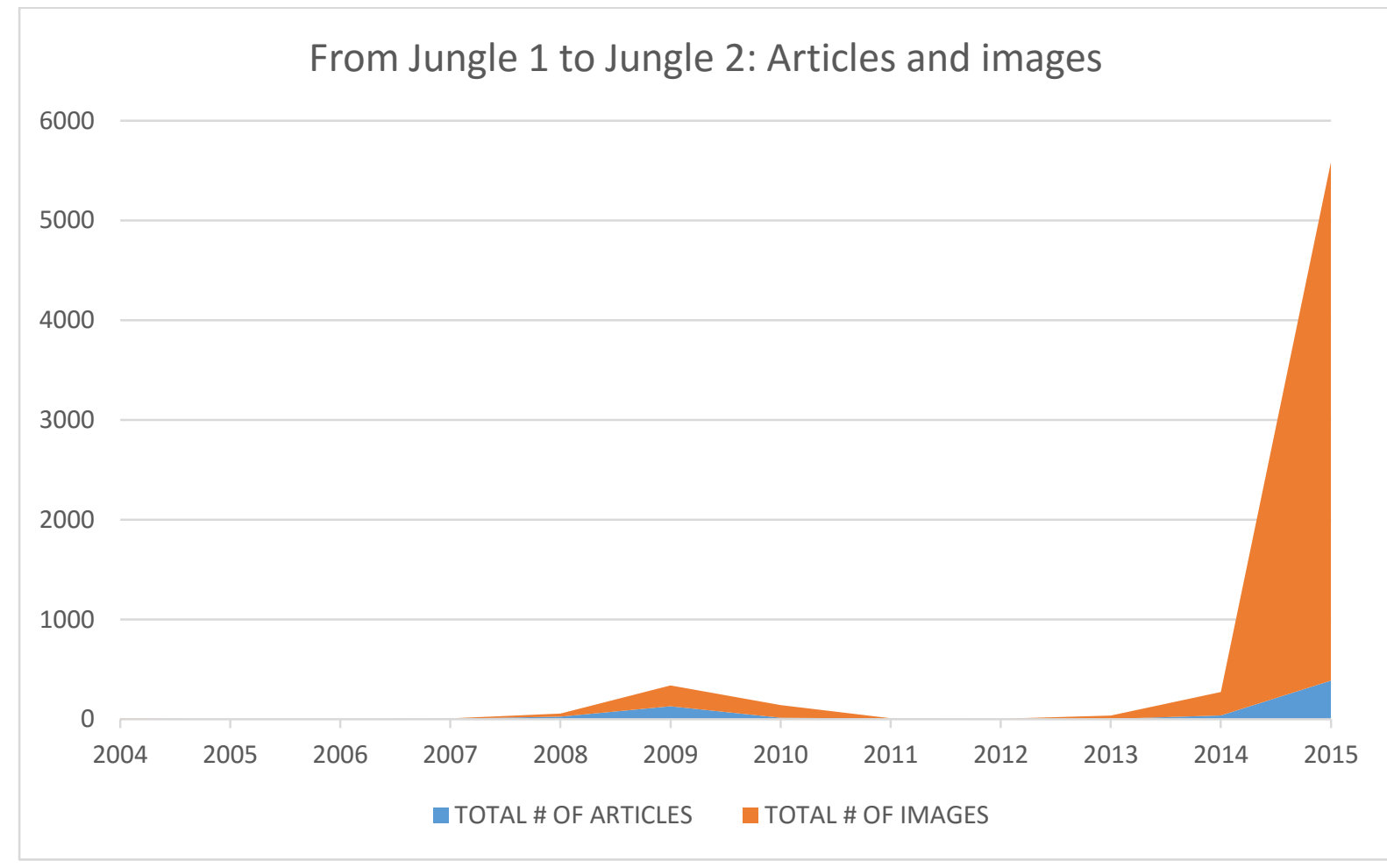

\begin{tabular}{|c|c|c|c|c|c|c|c|c|c|c|c|c|c|}
\hline & 2004 & 2005 & 2006 & 2007 & 2008 & 2009 & 2010 & 2011 & 2012 & 2013 & 2014 & 2015 & Totals \\
\hline $\begin{array}{c}\text { Number } \\
\text { of } \\
\text { articles }\end{array}$ & 6 & 0 & 2 & 7 & 27 & 131 & 16 & 7 & 2 & 5 & 39 & 388 & 630 \\
\hline $\begin{array}{c}\text { Number } \\
\text { of } \\
\text { images }\end{array}$ & 7 & 0 & 0 & 3 & 31 & 209 & 127 & 4 & 4 & 33 & 235 & 5195 & 5848 \\
\hline
\end{tabular}

Table 1: Articles and images of the migrant jungles of Calais

The Calais refugees and the demolition of the camps courted media attention in 2009 and the number of stories on the crisis gained prominence again from April 2014 (See Table 1). The Calais crisis came back into media scrutiny due to bigger events in the Mediterranean, where unprecedented numbers of refugees were risking their lives in overcrowded and rickety boats. From 2013 the death toll from shipwrecks in the Mediterranean rose as refugees fled conflict 
and persecution in North Africa, but in mid-April 2015 a smuggler's boat carrying 950 people, some locked in the hold, capsized off Libya's coast leaving only 28 survivors in what is believed to be the Mediterranean's deadliest known migrant tragedy. Coverage of Calais also surged (see Table 1) during the summer of discontent in 2015 when French ferry workers went on strike and blocked freight access to the port between June and September, causing major disruptions to truckers and holidaymakers. There was an unprecedented proliferation of coverage of the 'Calais crisis', but it also tended to fold in the wider migrations happening across the Mediterranean with refugees fleeing from Somalia, Eritrea and Syria. In Calais, the increased reporting and visuality of the camps was accompanied by an attendant curiosity in terms of what was creating agony for the holidaymakers, port workers and truckers. On 2 September 2015 the tragic image of Aylan Kurdi dead on the beach ignited further interest in the Calais crisis, which saw a surge in photo coverage of both the Mediterranean and Calais crises. This death event conflicted with the media spectacle where the public pity emerged through the exemplary of the dead child washed ashore. It led to increased curiosity about the crisis with the phenomenon of 'voluntourism', where volunteers started to converge on Calais both through curiosity and an emerging politics of pity (see Ibrahim 2010).

\section{Media Visuality and the Calais Refugee}

While vision is defined as an instrumental function of the eye, visuality entails a social way of seeing and experiencing through the visual. When we speak of 'visuality' rather than vision, we are referring to the cultural meanings consolidated in and as images. As such, visuality is not a pure seeing. For it is mediated in activities of image-making that cannot be entirely reduced to the visuality they constitute (Davis 2004, 9). In this sense, the article uses visuality where the image is produced within a cultural context and produces cultural and symbolic meaning beyond its immediate visuality. 'Visuality', then, refers to the 'constitutive character of symbolic renderings in the making of "experience" or a social reality' (Langer 1949, 393). In this case, it addresses media's modes of representation as evidenced through imaging and picturing the camp. We equally contextualise this visuality through the border politics of the camp.

The camp is a political site where law and order is suspended yet amenable to extreme forces of the sovereign state. For Agamben $(1998 ; 2000)$, the camp rather than the city becomes a biopolitical space of exception where the West in its sociological imagination of being under siege post-9/11 has increasingly implemented harsher immigration and asylum policies despite the legal instruments of human rights and their idealised normative of a democratic entity. Agamben invokes the need to review the notion of the spatial politics of power, particularly the spatial logic of the camp in terms of inclusion and exclusion, belonging and dispossession. The Calais camps inhibiting an exceptional, marginal and peripheral space were rendered invisible and nonvisible as illegal entities. Labelled as a 'migrant camp' they are stripped of every political status and reduced completely to naked life (Agamben 1998; 2000). According to Agamben, camps are paradoxically both outside the normal juridical order and yet somehow internal to that order. As such, people in the camps 'move about in a zone of indistinction between the outside and the inside, the exception and the rule, the licit and the illicit' $(1998,40)$. He argues that in such a permanent spatial arrangement the refugees become produced as 'bare life' by sovereign powers. The bare life becomes the reference in distinguishing the 'politically qualified' subject and equally in shoring up the borders of a sovereign political community. 
Agamben's homo sacer or bare life envisaged the expendable and wounded as both the target of sovereign violence and state of exception. For Agamben, bare life is 'a zone of indistinction and continuous transition between man and beast' $(1998,109)$. As such, the inclusion in the polis is precisely through its exclusion and through unlimited violation which is not deemed illegal. Hence, Western biopolitics is defined through the sovereign power and bare life. Homo sacer as a figure stands outside human and divine law while being the object of sovereign violence, which exceeds the force of law and yet is authorised by the law. The banished figure of the homo sacer can be killed with impunity yet not deemed sacred for religious sacrifice or as a political subject to be accorded juridical law. For Agamben, as modern politics becomes a quest for new racialised and gendered targets in the politics of exclusion, they create a category of the 'living dead' $(1998,130)$. The refugee, the migrant or the inmates of Guantanamo Bay become the manifest species of bare life, reflecting the new forms of domination and the hidden ground within Western democracies; here the borders can ignite these regimes of control through policies of exclusion, a suspension of law, a state of exception, or at times an indistinction between norm and exception.

It is within this paradigm of perceptual space we locate the refugee camps of Calais. In consuming them visually through the media narratives, there is a politics of visuality (see Mirzoeff 2011) which unfolds from the setting of the context in media coverage of 'Jungle I' which was destroyed in 2009. Here the inhabitants were constructed through a border politics as illegal corporeal bodies presenting material risks to the ordered spaces of white suburbia and as economic opportunists seeking to storm into Britain to exploit their liberal benefit system. They posed the risk of denigrating the environment with their uncouth and criminal activities. These dehumanised narratives made their deaths and accidents crossing the border not deserving of pity or empathy (See Ibrahim 2011; Ibrahim and Howarth 2015b; 2015c). The images on mainstream media news sites which accompanied the first 'jungle', invited public gaze through these readings of inserting order over the bodies which contaminated a porous fortress Europe (see, for example, Peake 2009). The surge in images in 2014 and the subsequent trauma of Aylan Kurdi's death image on the beach produced a counter-visuality which was as conflicted as the futility of the refugee predicament in Calais.

If Aylan Kurdi's images produced a disruption to the 'visuality' of the refugee crisis, it also coalesced with a moment in press reporting that looked beyond the cursory bodies damaged or demised through their passage across the borders. The new visuality surging through the proliferation of media images in 2014 and 2015 fragmented reporting on the issue where it was no longer able to ignore the disaster events of boats capsizing in the Mediterranean, particularly with Germany viewing the events as a humanitarian crisis despite the UK government's reluctance to be drawn into it. The increased gaze into the camps and its inhabitants since 2014 mark a moment of conflicted visuality where the refugee bodies are objects of interest and curiosity. Their personal spaces, bodily needs, and sanitation become objects of gaze which emerge through a discourse of cataloguing and documenting their depraved conditions, and in the process this gaze is just as disconcerting as the mammoth machine bulldozing their makeshift tents. It produces a gaze into the private realms without producing an intimacy to the Other. More importantly, it impresses the impasse in the political where the predicament of the refugees is entrapped in the border politics of violence. While the increased curiosity into the conditions of the refugee camp in Calais disrupted the earlier patterns of media reporting on the camp by enabling more visuality into the conditions of the camp, it by no means repudiated the refugee as 'bare life' in terms of them of being subjects of 'sovereign violence or the state of exception' (Agamben 1998). The visuality 
reproduced and accentuated their difference as sub-humans in the border politics of the state and within the turbulence of European Union (EU) politics of not providing a united front to refugee settlements. The refugee as an unwanted and castrated being of the sovereign was imagined through media visuality; basic amenities such as toilets and running water became consuming imagery in the reportage. The visuality or our modes of looking at the Other through increased media photo-imagery in fact reinscribed their distance and alien status.

\section{The Context of Irregular Migration into Europe}

Before embarking on the main themes produced by the visuality of the media, the study needs to be situated within the context of migration to 'fortress Europe'. Compared to the preceding years, the world was facing its biggest refugee and migration crisis since the Second World War in 2014 (United Nations High Commissioner for Refugees [UNHCR] 2015a). Millions of people, half of whom are children, have been uprooted due to conflict or persecution, and stranded on the edges of society as long-term internally displaced or as refugees. The degree of displacement as evident in the numbers of people forced out of their countries has required more co-ordination between states than before (UNHCR 2015b). The scale of irregular migration into the EU surged in 2011 with the onset of the Arab Spring in Tunisia and continued when sub-Saharan African refugees to Libya began to flee post- Gaddafi unrest in 2010-2011 (Park 2015). One major force of displacement has been the Syrian conflict, with further displacements in crisis zones, particularly Afghanistan, Somalia and Eritrea (UNHCR 2015b).

The EU has become a key destination for many from North Africa and the Middle East; however, the increased militarisation of the Mediterranean and the Calais borders has made it the 'most dangerous destination' for irregular migration in the world due to mortality rates (IOM 2014). According to the International Organisation for Migration's (IOM) estimates, more than one million migrants and refugees have reached Europe in 2015, many of whom did so by crossing the Mediterranean, and some 3,692 of which died in their attempts to reach Europe, outstripping the number of deaths in 2014 by more than 400 (Oliver 2015; IOM 2014). Though the EU is facing one of its biggest ever challenges, its response has been fragmented and ad hoc, with some governments welcoming Syrian refugees but not those from Eritrea, Somalia and Afghanistan. Others, for instance the British and Hungarian government, prioritized the securing of borders over the protection of the rights of migrants and refugees.

The privileging of security in policy responses is a retreat from discourses of according protection and rights to refugees which emerged after the Second World War in international agreements on how civilians should be treated in conflict; particularly the right to seek sanctuary, claim asylum, and avoid penalties for illegal entry in search of these. These dominant discourses in Europe have eroded in a series of major developments starting with the break-up of the former Soviet Union, the Eastern bloc and Yugoslavia in the 1990s, and more recently the turmoil in the Middle East and North Africa.

In Calais, a Red Cross shelter which had sought to provide sanctuary to refugees from the Balkans was closed down in 2002. The shelter was seen as a magnet for migrants seeking to enter the UK. By labelling them as migrants, both the UK and French governments sought to avoid arrangements for refugees warranted under international agreements. The Nicolas Sarkozy government placed a de facto ban on semi- or permanent shelters. By creating a 
spectacle of the demolition of the informal camps, they hoped to present it as a deterrent to more camps sprouting in 2009. The François Hollande government elected in 2012 in contrast came under increased pressure from local politicians, humanitarian organisations and the United Nations, which in 2015 labelled the living conditions of the refugees as an 'indictment on society' (Taylor 2015). Hollande's government equally had to respond to emergency measures to bring the informal camps up to minimum international standards in terms of running water, sanitation and lighting.

Beyond the stance of the UK and French governments to the scale of migration from conflict zones, the reaction of the newspapers to what they deemed and reported as a migrant problem is pertinent to the contextualisation of imaging Calais. The newspapers in the UK mirrored government's assertions that the issue should be cast through the lens of illegal immigration (Howarth \& Ibrahim 2012). As such, the negative depictions of the Jungle need to be located within the resumption of a decade-long 'media campaign' against immigration policies (Parliament 2007a). Most of Britain's national newspapers are ideologically conservative (Greenslade 2004); however, anti-immigration policy discourses are discernible across the broad political spectrum of British national newspapers (Ibrahim \& Howarth 2015c). Even before the Jungle, a dominant theme across all the newspapers was of immigration policy failure and the need to address this urgently. The most critical, though, were the mid-market titles such as the Express and Daily Mail which framed this failure in terms of government abdication of moral responsibility to protect Britons and migrants from exploitation by criminal networks.

\section{Analysis of the Images in the Newspaper Coverage}

We examined the images of the Calais crisis from 2003 to November 2015. We focused on the online versions of the four main tabloid newspapers - the Sun, the Mirror, the Express and Daily Mail as well as the five main qualities i.e. the Financial Times, The Times, the Telegraph, the Guardian and the Independent. The corpus also included the Sunday counterparts of tabloids and broadsheets, except for the Sun. We also supplemented this with a search on UK Online database in order to capture those articles and images on the 'jungle' that predate newspaper online archives. Our search on 'Calais and jungle' between 2000 and 2015 generated 630 articles and 5,488 images (See Table 1) with first mention of 'the Jungle' in August 2004 (Coates 2004).

Our analysis needs to be located within a wider newspaper campaign against immigration that peaked in 2003, followed by a lull and a subsequent surge, with 2500 articles between early 2006 and early 2007 (Parliament 2007a, 55). The tone of coverage during this period was overwhelmingly hostile, drawing on emotive and pejorative language such as 'flood', 'bogus' and 'fraudulent' (Parliament 2007b, 99) and contributing to the 'dehumanizing' of asylum seekers (Parliament 2007b, 98) and a 'misleading picture' of immigration which 'fuelled political prejudice and extremism' in the UK (Parliament 2007b, 55). Newspapers also portrayed the continued presence of ' 400,000 illegal immigrants' as policy failure in terms of immigration and the asylum system (Parliament 2007b, 55). It was in this context of heightened tensions that Britain's mid-market newspapers reported on 'the Jungle' between 2007 and 2010, associating it with environmental denigration, barbarism, criminality and illegality. The pseudo-rational discourses of immigration policy failure and the transgression of boundaries were instrumental in enacting the refugee as a deviant, deliberately disentangling them from the dimensions of human suffering. Our basic content analysis of the 
ebbs and flows in coverage of 'the Jungle' found a marked increase in media coverage from 2014 onwards (see Table 1). We were able to discern two distinct phases in the Jungle camps; a period before 2009 when the main Jungle camp was destroyed and a period after, when new smaller 'jungles' emerged. There was a lull in the reporting from 2011 till 2013, followed by a steep surge in reporting in 2014, particularly in terms of the images which either accompanied reports or formed part of the online slide shows in newspaper websites.

We mined 630 articles and in coding 5,488 images we were led by overarching dominant discourses and the conceptual frameworks of the liminal border politics; policies of the UK and French governments and the flow of migration to EU, the hostility of media in earlier reporting (i.e. 2003 to 2009) and the 'state of exception' which applied in governing refugee bodies and lives. The main themes which emerged from our conceptual frames include the notion of destruction, brutality and violence as evident in the demolitions, injury and death, and the movement of refugees captured by their desperate acts to cross the border into the UK. Other themes include the emergence of the notion of a quasi-settlement through imagery which contrasts with the earlier destructions where the material and physical settlement affirms the lack of a permanent solution for the refugee situation in Calais, held together mainly through the endeavours of volunteers and the non-governmental organisation (NGO) communities. The material and physical site of jungle II alludes to the fact that there is no limit in terms of time to the incarceration in the camps. Some of the themes here are intertextual through wider migrations to the Mediterranean, where the enlarging of the visuality dovetails with the public's disquiet over the drowning and deaths in the Mediterranean. The thematisation of the images was categorised through our conceptual arguments and hence are interpretive. In some cases, the images were amenable for classification under more than one theme. The categorisation of the themes was also led by the captions and headlines of the stories the images were a part of.

\section{Spectacle of Demolition, Violence and Brutality}

The depictions of violence in Calais are both embodied and spatially arranged through the politics of the border. Violence appropriates a duality; there is violence inflicted on refugees' bodies by their incarceration and there is the violence of the sovereign state in the liminal state of exception in Calais. This duality means that the displaced exercise power over their own bodies through the risk they take to cross the border. Equally, the sovereign state wields biopolitical power on these contaminants who weaken the security of their borders. The third aspect of violence is the camp itself, where the inhabitants pose further danger to themselves (i.e. women and children) demarcating the camp through its inherent atavism as a space of 'madness and despair' (Pugliese 2002). The interior gaze into the camp marks its instability within a wider context of violence unleashed on its inhabitants.

Joseph Pugliese (2002) argues that the spatio-temporal logic of the camp induces 'refugees to fall back on the one resource left to them in the midst of the violence of indefinite incarceration: their bodies. Even as the body is bounded and imprisoned, it can exercise a power that will elude the mechanisms of repression and the desire for absolute control'. The readings of violence accrue dialectically both in the refugees' appropriation of the only resource left to them (i.e. their corporeal body) and equally the sovereign powers' quest to control these expendable entities. The imaging of the Jungle as such unleashes an aesthetics of violence, captured in the refugees' interaction with the wider world and the authorities' 
initial attempts to outlaw the Jungle and in their subsequent attempts to contain them within the demarcated spheres.

The imaging of Jungle I was dominated by the spectacle of destruction in September 2009 with coverage in most national dailies (Daily Mail Reporter; Express 2009; Financial Times 2009; Peake 2009). These images centralised the machinery and its might in the destruction of the victim. The victims were diminished both in the lack of human focus on them and equally through their displacement. Their suffering was not centric in these images. These demolitions stylised for the observer as a media event sought to impress readers that the French were enacting spatial control over their territory and to overcome criticism that there was inertia in dealing with the refugees. The military-style demolition organised as a 'dawn raid' by riot police and flamethrowers, accompanied by bulldozers and chainsaws and in the full glare of the media was designed to quell public disquiet and to court the media gaze. A significant proportion of the British press welcomed the destruction of the camp as a sign that the French authorities were getting tough on the traffickers. The brutality as depicted through the images of tearful migrants and refugees remained as a prop in these imageries. These publicity stunts did not augur well with the French public and were perceived as futile in rooting out people traffickers (Hall 2009). The five camp demolitions in 2014 and 2015 repeated similar scenes of bulldozers and cranes with refugees watching helplessly as their shelters are destroyed and police restraining them from going back to salvage their belongings (Allen 2015b; Pickard 2014). These were on a smaller scale compared to 2009, and by November 2015 had become a non-event for most journalists.

The wounded, dead and traumatised refugee imageries were juxtaposed with those of police brutality and authorities being in control of the situation. Doctors working with refugees reported growing numbers of them with trauma injuries including broken bones and cuts from police violence and from falling off trucks. Images in the media corroborated some of these claims, capturing ongoing 'skirmishes' with refugees challenging the cordons, running from the police or fleeing the spray from canisters of tear gas fired by officers (Robinson et al. 2015). But the witnessing by the doctors remained separate from the media tracts where, for example, charities and NGOs were utilising new media platforms to highlight the plights of the refugees (See Ibrahim and Howarth 2015a).

The visual turn during the 2015 summer of discontent captured more graphically than before the brutality of militarisation, refugee-police engagements and the desperation of refugees leaping or sneaking aboard passing vehicles. Depictions of black smoke billowing from tyres set on fire by striking port workers combined with images of police cordons at the perimeter fence to the Channel Tunnel, and black-clad riot police armed with shields, batons and tear gas straddling railway lines and roads showcase the extent of their vigilante gaze and the depictions of the 'troubles, risks and inconveniences' presented by the refugees to the public and authorities (Milmo 2015; Gillman, Mullin \& Duffin 2015; Reynolds et al. 2015).

Beyond media representations, the imaging of Calais was expanded through user-generated content (UGC) captured through volunteers as well as those who encountered the scenes between the police and refugees in Calais. An inquiry was launched by a police watchdog after a video posted online by activist group Calais Migrant Solidarity (CMS) appeared to show officers stopping refugees on the road then shoving, kicking and beating them, pushing them over the guardrail and forcing them to the ground or spraying teargas at close range at refugees walking along the road (Samuel 2015; Chrisafis 2015). Another clip posted online revealed a Hungarian lorry driver deliberately swerving in front of the refugees in the Calais 
'war zone' and the inhabitants then scattering out of the way (Withnall 2015). Such encounters became a game of violence enacted on the refugees. These images of cruelty and brutality against the refugees expanded the theatre of violence. The mainstream media in exhibiting UGC on their websites provided a counter-visuality to the migrant crisis in Calais. The UGC in some parts also reinscribed the discourses of risk and paranoia evident from the 2009 reports of refugees invading white suburbia. A number of images showcased refugees breaking into the back of lorries travelling to Britain with news texts claiming migrants 'were running amok', a 'baying mob brought a motorway to a standstill' as Calais was described as facing an invasion and descent into 'anarchy' (Sheldrick 2015).

The desperation of the refugees during the summer of 2015 to enter the UK through the stalled vehicles in Calais was also captured in UGC, taken from a holiday coach of 'tourist terror' as migrants 'swarmed' around trucks and 'smashed their way' into the back of them (Newton 2015). The 'native encounters with the jungle inhabitants' as such produced new forms of exhibits and imaginaries of the 'migrant'. These native encounters coalesced with images in media reports showing refugees walking or running alongside railway tracks littered with accounts of a teenager electrocuted climbing through holes in the old fencing or dangling a small child over it (Millar 2015; Sage 2015). There were also images of refugees clinging to the top of trucks or hanging onto the undercarriage, squeezing into tight spaces behind the cab or sneaking into the back then being forcibly removed by the police if spotted. Risk, death and injury became images of normality, and violence was inscribed as a corporeal reality as refugees sought to break free of their predicament.

The tragic consequences of such desperate measures were poignantly captured in images of a makeshift cemetery where wooden crosses mark the spots where 28 refugees have been buried in Calais, and one headstone marks the grave of baby Samir Khedija whose Eritrean mother had a miscarriage during an attempt to travel from Calais to England (Hill 2015). With women and children not immune to police violence, an up-close image captured a large bruise on the upper arm of a 16-year old girl which she alleges was the product of a police baton (Thornhill 2014). Images also capture women and girls scrambling through fences in a bid to board a freight train and of a young man pulling a toddler over a barbed wire fence before helping her drop to the ground close to the high-speed tracks (Millar 2015), those of children walking along the side of the road or the railway tracks and of a 10-year-old Eritrean boy squeezed into a gap in a cab by his 17-year-old brother who vowed to get him to Britain before making the journey himself (Kelly 2015). Children as the most precious commodity of the refugees become part of this violent imagery in their struggle to redeem some form of legal status.

The spectacle of violence which engulfs the refugee's body makes it exemplary and an instrumental weapon in warding off other prospective asylum seekers from repeating this passage (Pugliese 2002). The theatre of violence is part of the border politics of Calais, where the spatial politics inscribe the refugee bodies with violence, highlighting their expendability and equally the denigration of a humanitarian crisis into a 'deviant migrant' discourse of opportunism, hence absolving the state of its moral or legal obligations.

\section{The Physical Site of the Camp}

The shift from destruction of flimsy tents to the provision of semi-permanent shelters occurred incrementally in 2014 and 2015. It was accelerated after a French court order gave 
authorities eight days to implement emergency measures to bring living conditions up to minimum international standards for refugee camps with the government allocating $€ 18$ million (£12.7 million) to do so (Holehouse 2015). Thus there is an increasing emphasis in images which install the semi-permanence of the camps through the provision of basic amenities. Making the camp a quasi-settlement infuses a 'spatio-temporal logic where the figure of the homo sacer is confined and bounded by the spatial-materiality of the camp, strictly delimiting the refugees' freedom of movement and marking the material borders of their existence. Due to the indefinite nature of the detention, the refugee is sentenced to a temporal open-endedness that knows no limits' (Pugliese 2002). As such, Pugliese argues, the "incarcerated refugee is forced to experience the vertiginous violence of "imprisonmentin-infinitude" which becomes the locus of the madness and the despair generating the uprisings and revolts in the detention centres'.

The consolidation of Jungle II as a quasi-settlement was depicted through aerial images showing it trebling in size into a mini-metropolis with a mosque, church, shops and market, Wi-Fi/charging station and theatre (Akbar 2015; Tomlinson 2015a; Charlton 2015). The aerial views became cartographic impressions of its growth and in many ways it confirmed the fears of French and UK authorities as a jungle sprawling out of control and infiltrating their ordered spaces.

Perhaps the most graphic divergence from Jungle I was the beginning of a sanitation system, not in the form of permanent waste-water piping but in the provision of 50 chemical, portacabin toilets commonly used on building sites (Kelly 2015). Earlier narratives and images of the camp portrayed it in squalor, filth, excrement and stench. As such, the images of portacabins and flushing toilets seem to suggest lifting the savage from his defecation-filled existence into redemption through the provision of basic amenities which he was not entitled to earlier. After a sustained criticism from UNHCR about the lack of standards in the camp, the French authorities announced they would make the 'New Jungle' a 'permanent fixture by providing running water and electricity to the site' (Hall \& Sparks 2015). The images in 2014 and 2015 captured these transitions, such as refugees clustered around a mobile-charging site using multi-socket adaptors powered by a generator (Chazan 2015; Perring 2015). The savage of Jungle I who was constantly robbed of his belongings and shelter was resurrected in these images with the ability to charge telecommunication equipment. Nevertheless, despite his redemption through sanitation, the camp is forever saturated and associated with filth through images of litter, uncollected refuse, old boxes of food surrounded by rats and infused with the smell of human waste.

The quasi-settlement was depicted in images of 'grassroots' businesses including shops which sold a range of goods including food, cigarettes, and SIM cards, and a bicycle repair shop. Entertainment facilities also emerged in the form of impromptu bars and a theatreturned-nightclub (Tomlinson 2015b). Volunteers and donors set up a school for the teaching of English and French, a library called 'Jungle Books' and a reading room, as well as different churches and a mosque (Allen 2015a). The most captured of which was the makeshift Ethiopian Orthodox church, constructed out of wood and tarpaulin with rugs and icons decorating the inside, which was the subject of a BBC religious programme (Ledwith \& Allen 2015; Press 2015).

Secondly, the camp was no longer gendered through male presence. In 2014 and 2015, the first semi-formal shelters for women and children began to open in response to the increasing numbers of 'lone women queuing up' to get into Britain and 'desperate mothers dragging 
their babies 5000 miles' to Calais (Ellicott 2014; Smith, Lane \& Fidler 2015). On the instigation of Natacha Bouchart, the mayor of Calais, new 'Sangatte-style' sheltered accommodation was opened for them and, after a court order in October 2015, authorities began for the first time to identify children arriving in the camp. Although some women and children stayed in the shelters, these filled up within weeks and the rest were forced to live in the Jungle II camp. The Jungle as a space of insistent and sustained violence is communicated through the fears and anxieties of women and children incarcerated there. The media reports revealed that women had admitted to sleeping six to a tent for security reasons as they lived in constant fear of being raped after dark when men would drink and fight. Mothers with their children reportedly hid in tents during the day or inside a locked detention centre to avoid being assaulted by the men around them. Others had reportedly been forced into prostitution by pimps as a way of protecting themselves against gangs, and one charity claimed it locked the gates at night to protect the women and children in its shelter.

The intrusive gaze into the private realms of the refugee created an aesthetic of violence as well as an acknowledgement of the refugee body as a non-sacred entity, as the notions of 'private' and 'public' become blurred in the camp through the transgressive media gaze and public consumption of the camp. The imagining of Jungle I had included snapshots of daily life in the camp, but these were mainly outside scenes with a glimpse from a distance into a mosque with Muslims praying before the raid and the occasional photograph taken inside a tent of bedding and clothes or of baking bread. In contrast, media attention on Jungle II, at least from August 2015, expanded to include the visualisation of life inside the jungle. Some created the appearance of 'normality among the harsh conditions' (Smith 2015) including refugees relaxing with 'universal' pleasures such as playing football or dominoes and women and children talking in groups outside the church, a typical scene in many parts of the world where Christians gather on Sundays. Activists also set up a 'Jungle nightclub fitted with sound system and flashing lights and a bar' and the 'Good Chance Theatre' seen by critics as evidence that these were 'economic migrants' not refugees (Tomlinson 2015b).

Despite reports and images which sought to look inside the camps, these constituted a form of constructed aesthetics to visualise the Other. While it disrupted the earlier hostile reports of the Jungle I, the more intrusive gaze of Jungle II reignited the dispossessed nature of the camp and its inhabitants, where their lives and predicaments are public but the resolution a private matter for them to confront and encounter through the risks they take with their own bodies or those they inflict on their most sacred possessions (i.e. their offspring), reiterating Pugliese's (2002) prophecy of the camp as a space of madness and despair.

\section{Conclusion}

The visual turn in imaging the refugee crisis in Calais in 2014 and 2015 needs to be contextualised against earlier media representations of Jungle I. The increased and interiorized gaze of Jungle II offers a counter-visuality to earlier depictions of the refugee settlements. This counter-visuality, while not completely dichotomised from the communal politics of pity, produces the camp as an unresolved site of human struggle. The gaze afforded through the media enables both material and symbolic readings of the camp in analysing the images. As a site of unresolved human trauma, the visuality produces a sustained documentary of instability produced through war, strife and conflict across the world. The camp freezes time and space, entrapping its inhabitants in a bubble of futility while their lives are on hold infinitely. The media gaze opens up yet more probing ethical 
questions on the plight of the homo sacer (i.e. the refugee) the by-product of sovereign power; constituted by it yet disowned through its politics of exclusion.

\section{References}

Agamben, G. (1998) Homo Sacer: Sovereign Power and Bare Life, Stanford, California: Stanford University Press.

Agamben, G. (2000) Means Without End: Notes on Politics, Minneapolis: University of Minnesota Press.

Akbar, J. (2015) 'It's an Even Bigger Jungle Out There: Aerial Photographs Show the Calais Migrant Camp has Grown in Size in Just Three Months as the Number of People Living There hits 4,000', Mail Online. [Online]. Available at http://www.dailymail.co.uk/news/article-3256653/It-s-bigger-jungle-Aerial-photographsCalais-migrant-camp-rapidly-increased-size-just-three-months-number-people-living-hits-4000.html Accessed 15 December 2015

Allen, P. (2014) French to Bulldoze Camp Where Hundreds of Immigrants are Gathering to Enter Britain Illegally as a 'Risk to Public Health', Mail Online[Online]. Available at http://www.dailymail.co.uk/news/article-2636335/French-bulldoze-camp-hundredsimmigrants-are.html Accessed 15 December 2015

Allen, P. (2015a) 'French Police Injured in Clashes with Brit Bound Migrants in Calais', The Express. [Online]. Available at http://www.dailymail.co.uk/news/article-2636335/Frenchbulldoze-camp-hundreds-immigrants-are.htm Accessed 15 December 2015

Allen, P. (2015b) 'Here We Go Again: Police Surround Squalid and Germ-Ridden Calais Camp as they Prepare to Remove Another 800 Immigrants Waiting to get to Britain', Mail Online. [Online] Available at http://www.dailymail.co.uk/news/article-2640906/Policesurround-Calais-camp-prepare-remove-migrants.html Accessed 15 December 2015

Charlton, J. (2015) 'Refugee Crisis: What Life is Really Like Inside the "Jungle” in Calais', The Independent, 01 October. [Online]. Available at http://www.independent.co.uk/news/world/europe/refugee-crisis-what-life-is-really-likeinside-the-jungle-in-calais-a6674256.htm Accessed 15 December 2015

Chazan, D. (2015) 'Row Over Planned $£ 213 \mathrm{~m}$ Calais Theme Park Alongside Migrants' Camp', The Telegraph. 01 November [Online]. Available at http://www.independent.co.uk/news/world/europe/refugee-crisis-what-life-is-really-likeinside-the-jungle-in-calais-a6674256.html Accessed 15 December 2015

Chrisafis, A. (2015) 'French Police Watchdog Investigates Video of Alleged Abuse of Calais Migrants', The Guardian. 13 May [Online]. Available at http://www.theguardian.com/world/2015/may/13/french Accessed 15 December 2015

Coates, S. (2004) 'Desperate Refugees Hide in "Jungle” Outside Calais', The Times, 25 August. [Online]. Available at

http://www.thetimes.co.uk/tto/news/uk/article1928205.ece Accessed 15 December 2015

Daily Mail Reporter (2009) 'Razed to the Ground: Jungle Migrant Camp Emptied After Raid by Calais Police (But Will it Stop Asylum Seekers Flooding into Britain?)', Mail Online, 22 September. [Online]. Available at http://www.dailymail.co.uk/news/article1214161/French-Jungle-razed-week-immigrants-told-You-England-anymore-Calais.html Accessed 15 December 2015 
Davis, W. (2004) 'Visuality and Pictoriality', RES: Anthropology and Aesthetics, 46, 9-31.

Ellicott, C. (2014) 'Now Desperate Mothers Drag their BABIES 5,000 miles to Squalid Calais Refugee Camps to Find Husbands who Have Already Crossed Channel into Britain', Daily Mail, 23 October. [Online]. Available at http://www.dailymail.co.uk/news/article2804580/Now-desperate-mothers-drag-BABIES-5-000-miles-squalid-Calais-refugeecamps-husbands-crossed-channel-Britain.html Accessed 15 December 2015

Express (2009) 'Migrant “Jungle” Camp Bulldozed', The Express, 22 September. [Online]. Available at http://www.express.co.uk/news/world/129163/Migrant-jungle-camp-bulldozed Accessed 15 December 2015

Financial Times (2009) Slideshow: French Migrant Clampdown. Financial Times, 22 September. [Online]. Available at http://www.ft.com/cms/s/0/22b549b4-a770-11de-946700144feabdc0.html\#slide9 Accessed 15 December 2015

Gillman, O., Mullin, G. \& Duffin, C. (2015) 'Your Summer Holidays Have Gone up in Smoke: British Families Start Cancelling Holidays to France as Crisis in Calais Grows After Striking Ferry Workers Block Roads With Burning Tyres', Daily Mail, 31 July. [Online]. Available at http://www.dailymail.co.uk/news/article-3181242/Strike Accessed [15 December 2015]

Greenslade, R. (2004) Press Gang: How Newspapers Make Profits From Propaganda, Basingstoke: Pan Macmillan.

Hall, B. (2009) 'Refugee Groups Attack Police Clearance of Calais Camp', Financial Times, 23 September. [Online]. Available at http://www.ft.com/cms/s/0/ac3766b8-a7d9-11deb0ee-00144feabdc0.html?siteedition=uk Accessed 15 December 2015

Hall, J. \& Sparks, I. (2015) 'Shops, An Electronics Hub and a Makeshift Mosque Marked Out by Water Bottles: Inside The Calais Jungle Where 3,000 Migrants Laying Siege to Britain are Turning a Temporary Home into a Town', Mail Online, 4 August. [Online]. Available at http://www.dailymail.co.uk/news/article-3184708/Eurotunnel-passengers-face-two-halfhour-delays-operators-inspect-tunnel-days-2-500-migrants-stormed-crossing-Frenchminister-pleads-British-help.html Accessed 15 December 2015

Hill, P. (2015) 'Sadness of the Calais Jungle as Makeshift Cemetery of Simple Wooden Crosses Grows', Sunday Mirror, 31 October. [Online]. Available at http://www.mirror.co.uk/news/world-news/sadness-calais-jungle-makeshift-cemetery6743061 Accessed 15 December 2015

Holehouse, M. (2015) 'Migrant Crisis: European Council President Tusk Warns Schengen on Brink of Collapse', The Telegraph, 13 November. [Online]. Available at http://www.telegraph.co.uk/news/worldnews/europe/eu/11991098/Migrant-crisis-DonaldTusk-warns-that-Schengen-is-on-brink-of-collapse-latest-news.html Accessed 15 December 2015

Howarth, A. \& Ibrahim, Y. (2012) 'Threat and Suffering: The Liminal Space of 'The Jungle'. in H. Andrews \& L. Roberts (eds), Liminal Spaces, London: Routledge, pp. 200-216

Ibrahim, Y. (2010) 'Distant Suffering and Postmodern Subjectivity: the Communal Politics of Pity', Nebula, 7(1/2), 122-135. [Online]. Available at

http://content.ebscohost.com/ContentServer.asp?T=P\&P=AN\&K=51594697\&S=R\&D=hlh \&EbscoContent=dGJyMNHX8kSeqLE4y9fwOLCmr0ueprRSsa64TbWWxWXS\&Content Customer=dGJyMPPZ8oTn2LmF39/sU+Pe7Yvylnhttp://search.ebscohost.com/login.aspx? direct=true $\& \mathrm{db}=\mathrm{hlh} \& \mathrm{AN}=51594697 \&$ site. . Accessed 15 December 2015 
Ibrahim, Y. (2011) 'Constructing the Jungle, Distance Framing in the Daily Mail', International Journal of Media and Cultural Politics, 7(3), 315-331.

Ibrahim, Y. \& Howarth, A. (2015a) 'Sounds of the Jungle: Re-Humanizing the Migrant', JOMEC, 7. [Online]. Available at http://www.cardiff.ac.uk/jomec/research/journalsandpublications/jomecjournal/7 june2015/index.html Accessed 15 December 2015

Ibrahim, Y. \& Howarth, A., (2015b) 'Space Construction in Media Reporting: A Study of the Migrant Space in the "Jungles" of Calais', Fast Capitalism, 1(12). Accessed at: http://bura.brunel.ac.uk/handle/2438/11323

IOM (International Organization for Migration) (2014) Fatal Journeys: Tracking Lives Lost During Migration. [Online]. IOM: New York http://www.iom.int/statements/iom-releasesnew-data-migrant-fatalities-worldwide-almost-40000-2000 Accessed 15 December 2015

Kelly, T. (2015) 'Up you Go! Brother Hoists Boy of just TEN onto Calais Lorry Bound for Britain as Shock Figures Show Number of Stowaways to the UK has surged by 200 per cent in just a year', Daily Mail, 25 June. [Online]. Available at http://www.dailymail.co.uk/news/article-3139602/Up-Boy-just-10-helped-Calais-lorrybound-Britain-number-stowaways-UK-surges-200.html Accessed 15 December 2015

Langer, S. K. 1949. 'On Cassirer's Theory of Language and Myth', in P. A. Schilpp (ed.), The Philosophy of Ernst Cassirer, Evanston: Northwestern University Press, p. 393.

Ledwith, M. \& Allen, P. (2015) 'The Roof is Held up by Prayers and Duct Tape, While the 'Pastor' Was Made Priest Because He Studied Theology - but to Hundreds of Calais Migrants, Their Camp Church has become a Miracle of Faith', Mail Online, 9 August. [Online]. Available at http://www.dailymail.co.uk/news/article-3187754/The-roof-heldprayers-duct-tape-pastor-priest-studied-theology-hundreds-Calais-migrants-camp-churchmiracle-faith.html Accessed 15 December 2015

Lemanski, D. (2004) 'Woodland Lair of Despair; Inside the Asylum Jungle', Daily Star, 29 August p.3 [Print].

Millar, J. (2015) 'Calais Crisis: Incredible Photos Show Migrants Clinging to Speeding Lorry Roof on Motorway', The Express, 31 July. [Online]. Available at http://www.express.co.uk/news/world/595241/calais-migrants-roof-lorry-folkestone Accessed 15 December 2015

Milmo, C. (2015) 'David Cameron Admits Calais Crisis Will Last all Summer', The Independent, $31 \mathrm{July}$. [Online]. Available at http://www.independent.co.uk/news/world/europe/david-cameron-admits-calais-crisis-willlast-all-summer-10431508.html?origin=internalSearch Accessed 15 December 2015

Mirzoeff, N. (2011) 'The Right to Look', Critical Inquiry, 37(3), 473-496.

Newton, J. (2015) 'Tourists' Terror at Calais: Coach Passengers Capture Shocking Footage as Migrants Surround Their Vehicle and Smash Their Way onto a Lorry Heading to the UK', Daily Mail, 15 June. [Online]. Available at http://www.dailymail.co.uk/news/article3124280/Tourists-terror-Calais-Coach-passengers-capture-shocking-footage-migrantssurround-vehicle-smash-way-lorry-heading-UK.html Accessed 15 December 2015

Oliver, C. (2015) 'More than $1 \mathrm{~m}$ refugees arrive in Europe', Financial Times, 22 December. [Online]. Available at http://www.ft.com/cms/s/0/b5877722-a8b7-11e5-97002b669a5aeb83.html Accessed 15 December 2015 
Park, J. (2015) Europe's Migration Crisis, New York: Council on Foreign Relations.

[Online]. Available at http://www.cfr.org/migration/europes-migration-crisis/p32874 Accessed 15 December 2015

Parliament (2007a) Travis. P. Oral Evidence to Joint Committee on Human Rights. The Treatment of Asylum Seekers, London: Stationery Office. [Print].

Parliament (2007b) United Nations High Commissioner for Refugees. Written Evidence to Joint Committee on Human Rights. The Treatment of Asylum Seekers, London: Stationery Office. [Print]

Peake, A. (2009) 'Cops Clear "Jungle"', The Sun, 23 September. [Online]. Accessed [15 December 2015]

Perring, R. (2015) 'Calais Life Inside the "Jungle": Migrant Camp Boasts Shop, Barbers and Phone Charge Points. The Express, 5 August. [Online]. Available at http://www.express.co.uk/news/world/596239/Calais-migrant-crisis-Jungle-camp-shopbarbers-phone-charger-mosque Accessed 15 December 2015

Pickard, M. (2014) Riot Police sent to Clear Out Camp of Migrants Bound for UK. The Express, 4 August. [Online]. Available at http://www.express.co.uk/news/uk/495265/Riotpolice-clear-out-migrants-bound-UK Accessed 15 December 2015

Press, A. (2015) 'Many Feuding Faiths Coexist in Calais Migrant Camp in France. Daily Mail, 11 November. [Online]. Available at http://www.dailymail.co.uk/wires/ap/article3313444/Many-feuding-faiths-coexis Accessed 15 December 2015

Pugliese, J. (2002) 'Penal Asylum: Refugees, Ethics, Hospitality', Borderlands, 1(1).

[Online]. Available at http://www.borderlands.net.au/vol1no1_2002/pugliese.html Accessed 15 December 2015

Reynolds, M., Virtue, R., Campbell, S. and Little, A. (2015) Calais Goes UP IN FLAMES: Migrants Fight to get into UK as Ferry Workers Block Harbour', The Express, 31 July. [Online]. Available at http://www.express.co.uk/news/world/594851/Eurotunnel-Calaismigrants-Britain-Channel-Theresa-May-government-security-immigration Accessed 15 December 2015

Robinson, M., Glanfield, E., Ellicott, C. and Wright, S. (2015) 'Fury after PM Warns of "Swarm": As Police Seize Stowaway Migrants Across South, Cameron is Attacked For 'Likening Them to Insects', Mail Online, 30 July. [Online]. Available at http://www.dailymail.co.uk/news/article-3180063/British-police-stop-lorry-M20-just-15miles-Folkestone-arrest-12-migrants-patrols-stepped-sides-Channel-days-migrantsstorming-tunnel.html Accessed 15 December 2015

Sage, A. (2015) 'Lawless Scramble to get to Britain', The Times, 25 June. [Online]. Available at http://www.thetimes.co.uk/tto/news/uk/article4479217.ece Accessed 15 December 2015

Samuel, H. (2015) 'Police Inquiry Launched over Film Showing "Police Brutality" Against UK-bound Calais Migrants', The Telegraph. [Online]. Available at http://www.telegraph.co.uk/news/worldnews/europe/france/11600461/Police-inquirylaunched-over-film-showing-police-brutality-against-UK-bound-Calais-migrants.html Accessed 15 December 2015

Sheldrick, G. (2015) 'The Migrant Invasion: Dramatic Pictures show Calais Crisis Descend into Anarchy', The Express, 18 June. [Online]. Available at http://www.express.co.uk/news/world/585189/Calais-migrant-crisis-immigrantion-anarchy Accessed 15 December 2015 
Smith, S. (2015) 'Migrant Life in Calais' Jungle Refugee Camp - a Photo Essay', The Guardian, 10 August. [Online]. Available at http://www.theguardian.com/media/nginteractive/2015/aug/10/migrant-life-in-calais-jungle-refugee-camp-a-photo-essay Accessed 15 December 2015

Sparks, I. (2010) Bulldozing of Calais Jungle Immigration Camp was a "Publicity" Stunt Aimed at Placating the British public', MailOnline. [Online]. Available at http://www.dailymail.co.uk/news/article-1242854/Calais-Jungle Accessed 15 December 2015

Taylor, M. (2015) 'UN Migration Representative: Calais Camp is an Indictment on Society', The Guardian, 23 September. [Online]. Available at http://www.theguardian.com/world/2015/sep/23/un-migration-calais-jungle-camp-petersutherland Accessed 15 December 2015

Thornhill, T. (2014) 'Calais Under Siege: Migrants March Through Streets Demanding Human Rights Protection Amid Warnings French Port is being Overwhelmed', Mail Online, 5 September. [Online]. Available at http://www.dailymail.co.uk/news/article2744837/Alarming-footage-emerges-migrants-vaulting-16-foot-fence-ferries-Calais-amidwarnings-shutting-port-just-problem-elsewhere.html Accessed 15 December 2015

Tomlinson, S. (2015a) Astonishing Aerial Images Show How the Calais Migrant Camp has Sprawled to the size of a Small Town that is now home to some 5,000 refugees (and even has its own Farm, Mosque and Shop)', Mail Online, 23 July. [Online]. Available at http://www.dailymail.co.uk/news/article-3172042/Astonishing-aerial-image Accessed 15 December 2015

Tomlinson, S. (2015b) 'Now the Calais "Jungle" Camp has its own NIGHTCLUB: Migrants Post Photographs and Video From Dance Parties in tent set up by British Activists', Mail Online, 13 October. [Online]. Available at http://www.dailymail.co.uk/news/article3270521/Now-Calais-Jungle-camp-NIGHTCLUB-Migrants-post-photographs-video-danceparties-tent-set-British-activists.html. Accessed 15 December 2015

UNHCR (United Nations High Commissioner for Refugees) (2015a) High-Level UN Event Tackles Biggest Refugee and Migration Crisis Since Second World War. Geneva: UNHCR. [Online]. Available at

http://www.un.org/apps/news/story.asp?NewsID=52074\#.VnwXy1kSzAE Accessed 15 December 2015

UNHCR (2015b) Worldwide Displacement hits all-time high as War and Persecution Increase. Geneva: UNHCR. [Online]. Available at http://www.unhcr.org/558193896.html Accessed 15 December 2015

Withnall, A. (2015) 'Video Shows Hungarian Lorry Driver Deliberately Swerving at Refugees in Calais "War Zone", The Independent, 30 November. [Online]. Available at http://www.independent.co.uk/news/world/europe/video-shows-hungarian-lorry-driverdeliberately-swerving-at-refugees-in-calais-war-zone-a6754461.html. Accessed 15 December 2015

\section{Appendix: Image captions}

Akbar (2015). [Online]. Accessed [15 December 2015]

http://www.dailymail.co.uk/news/article-3256653/It-s-bigger-jungle-Aerial-photographs- 
Calais-migrant-camp-rapidly-increased-size-just-three-months-number-people-living-hits-4000.html.

- $\quad$ Crammed: Aerial images show how the Calais 'Jungle' has become an even more overcrowded settlement which is home to more than 4,000.

- $\quad$ Sparse: An aerial picture taken on 4 June 2015 shows how 'the Jungle' is expanding rapidly, with thousands of migrants flooding into Europe from Africa and the Middle East every day.

Allen (2014). [Online]. Accessed [15 December 2015] http://www.dailymail.co.uk/news/article-2636335/French-bulldoze-camp-hundredsimmigrants-are.html.

- $\quad$ France is to bulldoze camps containing hundreds of illegal migrants hoping to travel to Britain from Calais because of a growing danger to public health, it emerged today.

Allen, P. (2015) [Online]. Accessed [15 December 2015] http://www.dailymail.co.uk/news/article-2640906/Police-surround-Calais-camp-prepareremove-migrants.html.

- $\quad$ Some camp dwellers meanwhile barricaded themselves into makeshift huts, goading the police massing outside

- A bulldozer destroys the immigrant camp in Calais this afternoon

- A gendarme officer checks that a tent is empty as the bulldozer moves in to clear the site

Allen, P. (2015) [Online]. Accessed [15 December 2015] http://www.express.co.uk/news/world/618110/Jungle-Calais injured-police-French.

- $\quad$ Natasha Quarmby/REX Shutterstock - People attend lessons at the Jungle refugee camp, Calais, France

- $\quad$ The library at the Jungle refugee camp in Calais, France

- $\quad$ The reading room at the Jungle refugee camp in Calais, France

Associated Press (2015): [Online]. Accessed [15 December 2015] http://www.dailymail.co.uk/wires/ap/article-3313444/Many-feuding-faiths-coexist-Calaismigrant-camp-France.html\#ixzz3tusrcXs0

- Muslim migrants take off their shoes as they enter a makeshift mosque for Friday prayers at the migrant camp near Calais, northern France.

Charlton (2015). [Online]. Accessed [15 December 2015] http://www.independent.co.uk/news/world/europe/refugee-crisis-what-life-is-really-likeinside-the-jungle-in-calais-a6674256.html.

- Where the streets have no name: an aerial view of the Jungle camp (AP) 
Chazan (2015). [Online]. Accessed [15 December 2015]

http://www.telegraph.co.uk/news/worldnews/europe/france/11968673/Row-over-planned213m-Calais-theme-park-alongside-migrants-camp.html.

- A man pedals on a bike to generate electricity at a mobile phone charging station at the 'Jungle', a migrant and refugee camp, in Calais Photo: AFP

Chrisafis (2015) [Online]. Accessed [15 December 2015]

http://www.theguardian.com/world/2015/may/13/french-police-video-calais-migrants.

- Video posted online by Calais Migrant Solidarity appears to show police beating migrants on road to port

Daily Mail Reporter, 2009. [Online]. Accessed [15 December 2015]

http://www.dailymail.co.uk/news/article-1214161/French-Jungle-razed-week-immigrantstold-You-England-anymore-Calais.html.

- Wipe out: a bulldozer moves what's left of the once massive Jungle migrant camp into a pile.

- $\quad$ Police presence: Up to 500 officers raided the camp - one for each migrant.

- $\quad$ Seized: police officers grab one of the camp migrants today while another refugee tries to stop them.

- Wipe out: bulldozers, which had encircled the camp at the start of the raid, begin to rip down the tents.

- Violence: officers blocking off the migrants scuffle with them today as cameramen gather around.

- Hurt: a refugee cries while clasping his hand to the back of his head as a police officer escorts him off the site.

- Tears: an Afghan man cries as he is moved from his tarpaulin tent by police.

- $\quad$ Cleared away: tents and possessions are bulldozed into huge piles.

- Grab: a crane picks up what is left of the camp.

Ellicott (2014). [Online]. Accessed [15 December 2015]

http://www.dailymail.co.uk/news/article-2804580/Now-desperate-mothers-drag-BABIES-5000-miles-squalid-Calais-refugee-camps-husbands-crossed-channel-Britain.html.

- Women who have fled from Eritrea outside the tent they sleep in with other family members.

Express (2009). [Online]. Accessed [15 December 2015]

http://www.express.co.uk/news/world/129163/Migrant-jungle-camp-bulldozed.

- $\quad$ Police carry an Afghan man out of the 'Jungle' immigrant camp in Calais, France.

Financial Times (2009). Slideshow: French migrant clampdown. [Online]. Accessed [15 December 2015] http://www.ft.com/cms/s/0/22b549b4-a770-11de-9467-

00144feabdc0.html\#slide9. 
- $\quad$ Riot police jostle with protesters. The sweep by 500 police officers took place in front of scores of journalists and human rights campaigners tipped off about the operation.

- $\quad$ Some of the migrants cried as they were led away from the makeshift tent city.

- $\quad$ After removing the migrants the authorities set about clearing the camp of its makeshift plastic and cardboard shelters scattered between the bushes.

Gillman, O., Mullin, G. \& Duffin, C. (2015). [Online]. Accessed [15 December 2015] http://www.dailymail.co.uk/news/article-3181242/Striking-ferry-workers-burn-tyres-Calaisroads-causing-chaos-Brit-holidaymakers.html.

- $\quad$ Striking French workers scuppered plans to run extra ferries to France by blocking roads to the port with a wall of burning tyres this afternoon, bringing traffic to a standstill.

- $\quad$ Blaze: protesting employees of a ferry company have blocked roads to the port with a wall of burning tyres - another obstacle in British tourists' way.

- $\quad$ Rage: a protester throws fuel onto the flaming tyres near the port of Calais earlier today, holding up British holidaymakers as they try to pass.

Hill (2015). [Online]. Accessed [15 December 2015] http://www.mirror.co.uk/news/worldnews/sadness-calais-jungle-makeshift-cemetery-6743061.

- $\quad$ Escalating violence: increasing lawlessness in the Jungle camp is making it a dangerous place for immigrants to settle.

- Makeshift cemetery: wooden crosses mark the spots where 28 refugees have been buried in Calais.

- Heartrending: the grave of baby Samir Khedija whose mother had a miscarriage during an attempt to travel from Calais to England.

- $\quad$ Danger of death: the entrance to the Eurotunnel at Frethun, Calais

Kelly (2015). [Online]. Accessed [15 December 2015] http://www.dailymail.co.uk/news/article-3139602/Up-Boy-just-10-helped-Calais-lorrybound-Britain-number-stowaways-UK-surges-200.html.

- $\quad$ Off to start a new life: 10-year-old Aman Facih, from Eritrea, is bundled into a gap in a lorry by his brother Daniel amid chaos at Calais.

- $\quad$ Tight squeeze: he finally manages to push himself into a tiny gap in a French truck which drove off towards Calais and then on to Britain.

- A migrant walks past a toilet station in the makeshift camp known as the 'Jungle', in Calais. Many hope for better job prospects in Britain.

Ledwith, M., \& Allen, P. (2015). [Online]. Accessed [15 December 2015] http://www.dailymail.co.uk/news/article-3187754/The-roof-held-prayers-duct-tape-pastorpriest-studied-theology-hundreds-Calais-migrants-camp-church-miracle-faith.html.

- House of God: migrants come from across 'the Jungle' to attend the daily services at St Michael's Calais, which was constructed after several months of hard work.

- Decorative: the makeshift church has been furnished with ornate carpets and portraits of Jesus, giving it a real feel as a church/ 
- $\quad$ Lovingly made: migrants built the small church out of long sheets of taped together tarpaulin and planks of wood. Fashioned out of wood, a large crucifix is positioned on the roof of the building

Millar (2015) [Online]. Accessed [15 December 2015] http://www.express.co.uk/news/world/594851/Eurotunnel-Calais-migrants-Britain-ChannelTheresa-May-government-security-immigration.

- $\quad$ Migrants cling precariously to the top of a lorry in Folkestone.

- $\quad$ A migrant lifts his small child over a security fence.

Newton (2015) [Online]. Accessed [15 December 2015] http://www.dailymail.co.uk/news/article-3124280/Tourists-terror-Calais-Coach-passengerscapture-shocking-footage-migrants-surround-vehicle-smash-way-lorry-heading-UK.html.

- In footage filmed by passengers on a coach heading to Britain, migrants can be seen sneaking on to the back of a moving lorry.

- After two men successfully climb aboard the lorry another four men try and force themselves on to stow away to Britain.

- The passengers on the coach can be heard expressing their shock as the tour guide tries to reassure them telling them not to panic.

Peake (2009) [Online]. Accessed [15 December 2015]

http://www.thesun.co.uk/sol/homepage/news/2649008/Jungle-migrant-camp-cleared-by-riotcops.html.

- $\quad$ Bulldozers clear the makeshift camp known as 'the Jungle' AP (Peake, 2009)

-

Perring (2015). Accessed at: http://www.express.co.uk/news/world/596239/Calais-migrantcrisis-Jungle-camp-shop-barbers-phone-charger-mosque.

- $\quad$ Migrants charge their phones at the electronic hub.

Pickard, M. (2014) [Online]. Accessed [15 December 2015]

http://www.express.co.uk/news/uk/495265/Riot-police-clear-out-migrants-bound-UK.

- $\quad$ Up to 1,000 migrants in Calais face eviction and arrest today.

- $\quad$ Those held by police are often released within hours.

Reynolds, M. et al. (2015) [Online]. Accessed [15 December 2015]

http://www.express.co.uk/news/world/594851/Eurotunnel-Calais-migrants-Britain-ChannelTheresa-May-government-security-immigration.

- Smoke streams into the sky from tyres aflame.

Robinson, M., Glanfield, Emma, Ellicott, Claire and Wright, Stephen (2015). 'Fury after PM 
Warns Of "Swarm": As Police Seize Stowaway Migrants Across South'. [Online]. Accessed [15 December 2015] http://www.dailymail.co.uk/news/article-3180063/British-police-stoplorry-M20-just-15-miles-Folkestone-arrest-12-migrants-patrols-stepped-sides-Channel-daysmigrants-storming-tunnel.html.

- $\quad$ French police stand facing a group of migrants in an attempt to block their way into the Eurotunnel site in Coquelles near Calais last night.

- $\quad$ French police take up positions to block migrants who have entered the Eurotunnel site in Coquelles near Calais as the chaos continues.

- $\quad$ Migrants charge at a police cordon near the Eurotunnel in Calais tonight as they begin another attempt to flee the Continent for Britain.

- $\quad$ Losing battle: Heavily outnumbered French police try to stop a migrant trying to get to the Channel Tunnel yesterday and are now using tear gas to repel them.

- $\quad$ Pack mentality: The migrants are overwhelming police as they rush the Channel Tunnel in huge numbers last night as they desperately try to board trains knowing police are unlikely to chase them on the railway tracks

Sage (2015) [Online]. Accessed [15 December 2015]

http://www.thetimes.co.uk/tto/news/uk/article4479217.ece.

- A migrant clings to the undercarriage of a lorry.

Samuel (2015) [Online]. Accessed [15 December 2015]

http://www.telegraph.co.uk/news/worldnews/europe/france/11600461/Police-inquirylaunched-over-film-showing-police-brutality-against-UK-bound-Calais-migrants.html.

- $\quad$ Police intimidates migrants with a baton.

- $\quad$ Policeman caught kicking and hitting a migrant.

Sheldrick (2015) [Online]. Accessed [15 December 2015] http://www.express.co.uk/news/world/585189/Calais-migrant-crisis-immigrantion-anarchy.

- $\quad$ Pictures have shown how the Calais migrant crisis descended into anarchy.

- A baying mob brought a busy motorway to a standstill.

- Hooded men ran amok as migrants tried to board lorries in Calais.

Smith (2015). [Online]. Accessed [15 December 2015]

http://www.theguardian.com/media/ng-interactive/2015/aug/10/migrant-life-in-calais-junglerefugee-camp.

- $\quad$ Pregnant Syrian refugee Hanna is 24, five months' pregnant and says she cannot remember the last time she had a shower, let alone a medical check-up. She trekked through eight countries, her belly growing all the time, before ending up in Calais. Her husband is in Britain.

- $\quad$ Separation: women make up around $10 \%$ of the camp's population but have gone largely unnoticed, in part because early arrivals were secluded in a heavily guarded camp for women and children, but its 100 beds filled up long ago. 
- $\quad$ Relaxation: the camp residents find simple ways to socialise and relax on the site to try to maintain a sense of normality among the harsh conditions. A group of refugees from Sudan play dominoes. Most of them say they want to stay in France.

Thornhill (2014). [Online]. Accessed [15 December 2015] http://www.dailymail.co.uk/news/article-2744837/Alarming-footage-emerges-migrantsvaulting-16-foot-fence-ferries-Calais-amid-warnings-shutting-port-just-problemelsewhere.html.

- $\quad$ A 16-year-old Eritrean girl name Rita shows a fist-sized bruise on her upper arm where she claims police had hit her with a baton as she sits outside her makeshift shelter in the woods.

Tomlinson (2015b). [Online]. Accessed [15 December 2015] http://www.dailymail.co.uk/news/article-3270521/Now-Calais-Jungle-camp-NIGHTCLUBMigrants-post-photographs-video-dance-parties-tent-set-British-activists.html.

- $\quad$ Party time: migrants hold a rave at a nightclub set up in the Calais refugee camp dubbed 'the Jungle'.

Withnall (2015). [Online]. Accessed [15 December 2015] http://www.independent.co.uk/news/world/europe/video-shows-hungarian-lorry-driverdeliberately-swerving-at-refugees-in-calais-war-zone-a6754461.html.

- The driver says Calais has become a 'war zone' where 'the rules do not seem to exist'.

Dr Yasmin Ibrahim is a Reader in International Business and Communications at Queen Mary, University of London. Her ongoing research on new media technologies explores the cultural dimensions and social implications of the appropriation of ICTs in different contexts. Beyond new media and digital technologies she writes on political communication and political mobilisation from cultural perspectives. Her other research interests include globalization, Islam, visual culture and memory studies.

Email: y.ibrahim@qmul.ac.uk

Dr Anita Howarth's research focuses on the interaction between journalism/media, politics and risk. She has a particular interest in how traditional and social media engage with existing policies on social justice and (in)justice in ways that legitimize or challenge, resist or disrupt dominant perspectives. One track of her current research is looking at representations of $\mathrm{f}$ migrant 'jungles' of Calais and the struggles of the refugees against Fortress Europe and another strand looks at conflict over food contamination and food poverty.

Email: anita.howarth@brunel.ac.uk 